\title{
INDÍGENAS KAINGANG EM SANTA MARIA: ETNOGÊNESE E ESPAÇO URBANO
}

EDUARDO PERIUS ${ }^{1}$

UFSM, BRASIL

https://orcid.org/0000-0002-3934-6581

RESUMO: O presente artigo aborda a trajetória de indígenas Kaingang no contexto urbano de Santa Maria, ocorrido a partir de 1999. Através da análise de fontes de variados suportes, constitui-se um corpus documental plural, atentando para uma metodologia qualitativa capaz de abranger diferentes pontos de vista, garantindo uma concepção analítica complexa. Tendo como base interpretativa a Nova História Indígena, busca-se compreender as diferentes formas de atuar dos indígenas em um meio transformado pelas práticas colonizadoras empreendidas pelo Estado, principalmente a partir do século XIX com os aldeamentos, destacando o caráter ativo destes sujeitos na História. Utiliza-se o conceito de etnogênese para evidenciar a historicidade indígena, inserida em um âmbito dinâmico da cultura e etnicidade, apontando para a utilização de elementos do passado que, ressignificados no presente, servem como suporte para a luta coletiva na reivindicação de direitos e no reconhecimento identitário. Mecanismos como a Educação Escolar Indígena, a inserção em espaços públicos, a readaptação do artesanato para a comercialização, são tidos como essenciais no processo de etnogênese dos Kaingang de Três Soitas.

PALAVRAS-CHAVE: Kaingang, Aldeia Kaingang Três Soitas, Etnogênese, Nova História Indigena

\begin{abstract}
The following article approaches the trajectory of Kaingang Indians in the urban context of Santa Maria, which took place from 1999 onwards. Through the analysis of sources of varied supports, a varied documentary corpus is established, focusing on a qualitative methodology capable of covering different points of view ensuring a complex analytical conception. Based on the interpretative basis, the New Indigenous History, seeks to understand the different ways on acting of the indigenous in a medium transformed by the colonizing practices undertaken by the State, especially from the 19th century with the villages, highlighting the active character of these subjects in history. The concept of ethnogenesis is used to highlight the indigenous historicity, inserted in a dynamic scope of culture and ethnicity, pointing to the use of elements of the past that are re-signified in the present, serve as support for the collective struggle in the claim of rights and recognition of identity. Mechanisms such as Indigenous School Education, insertion in public spaces, readaptation of handicrafts for commercialization, are considered essential in the process of ethnogenesis of the Três Soitas Kaingang.
\end{abstract}

KEYWORDS: Kaingang, Kaingang Três Soitas Village, Ethnogenesis, New Indigenous History

\footnotetext{
${ }^{1}$ Mestrando pelo Programa de Pós-Graduação em História (PPGH) da Universidade Federal de Santa Maria (UFSM). E-mail: eduardo.perius@gmail.com
} 


\section{Introdução}

A presente pesquisa, resultante do exame de qualificação de dissertação apresentado ao Programa de Pós-Graduação em História da Universidade Federal de Santa Maria, trata da presença indígena da etnia Kaingang em contexto urbano, fato este que vem repercutindo no âmbito acadêmico e na sociedade em geral. Após décadas marcadas pela expropriação e degradação de seus territórios tradicionais e as tentativas do Estado de incorporá-los como trabalhadores nacionais, estes sujeitos dão continuidade aos movimentos reivindicatórios de direitos, marcando presença em centros urbanos para negociar com as autoridades. Em Santa Maria não é diferente, uma vez que passaram a lutar pelo espaço que é entre eles reconhecido como tradicional e o frequentam de forma mais sistemática desde 1999, adotando diferentes práticas a fim de garantir a subsistência física e cultural do grupo.

Para fins introdutórios e na tentativa de compreender as situações presenciadas na atualidade, é relevante uma reconstituição breve dos eventos que levaram aos fatos atuais no que concerne à organização dos indígenas e ao desenvolvimento de suas territorialidades após um longo processo de expropriação de seus territórios tradicionais. Tais políticas intervencionistas ganham maior força a partir do século XIX, quando o Estado brasileiro passa a investir cada vez mais em mecanismos buscando incentivar a vinda de imigrantes provenientes da Europa, situação esta que interferiu de forma negativa e prejudicial na manutenção das possibilidades de organização dos Kaingang no que se refere ao modo de vida sob padrões tradicionais. A questão da imigração alemã e italiana ganhou cada vez mais importância, o que gerou ocasiões em que os agentes históricos indígenas e imigrantes entrassem em conflito uns com os outros, resultando em violências, mortes e expropriações.

Uma obra que se mostra relevante para o amadurecimento e embasamento teórico neste quesito é "Fronteiras geográficas, étnicas e culturais envolvendo os Kaingang e suas lideranças no Sul do Brasil (18891930)" de Laroque (2007). O autor aprecia o surgimento de divergências de interesses e a gradativa redução das terras tradicionais ocupadas pelos Kaingang por meio do avanço da frente de expansão colonizadora.

A partir de 1845, com o objetivo de criar uma barreira entre estes dois grupos, o Estado adota a política de criação dos aldeamentos, ou seja, restringe a área de ocupação indígena por meio do estabelecimento de limites entre o que seria dos Kaingang e o que seria dos colonos. Neste momento, grandes porções de terra que eram tradicionalmente ocupadas foram remanejadas em nome do expansionismo agrário numa tentativa de aumentar a produtividade e o sucesso econômico.

Várias foram as estratégias adotadas com o intuito de garantir a subsistência dos grupos que se reorganizavam frente aos aldeamentos. Parte considerável que aceitava o aldeamento via-o como garantia de respeito de uma área delimitada e de seus respectivos recursos, possibilitando a sobrevivência física e cultural frente ao contexto transformado. Segundo Kujawa e Tedesco (2014) a 
aceitação do aldeamento e até a cooperação com a política imperial não significavam necessariamente uma lógica de subordinação, mas [...] uma estratégia de sobrevivência frente às disputas internas $e[\ldots]$ à modificação de seu habitat. (KUJAWA \& TEDESCO, 2014, p.72)

Apesar da redução drástica da área ocupada legalmente pelos Kaingang, foi constatado que estes permaneceram e permanecem exercendo suas territorialidades através da contínua circulação pelos territórios denominados tradicionais, incluindo os que vivem atualmente em Santa Maria na Aldeia Três Soitas, pois mesmo após muitos anos da expropriação de suas terras acabaram voltando para os lugares que estão presentes nas memórias coletivas.

Em 1910 é criado pelo governo brasileiro o Serviço de Proteção aos Índios e Localização de Trabalhadores Nacionais (SPILTN), a fim de desenvolver o que se conhece por regime de tutela, uma das responsabilidades do aparelho governamental federal. No Rio Grande do Sul, até o ano de 1917, sob o governo estadual de base ideológica positivista, buscava-se estabelecer os fundamentos e condições para a transformação dos indígenas em trabalhadores nacionais. Desta maneira, o objetivo era a assimilação dos indígenas para o sistema de produção agrícola, enquanto contribuintes ao desenvolvimento econômico do país.

A partir de 1918 é que se tem a atuação no Rio Grande do Sul somente do Serviço de Proteção aos Índios. De acordo com Laroque (2007, p.15), em "vista das modificações políticas, em 1918 a 'Localização dos Trabalhadores Nacionais' foi transferida para o Serviço de Povoamento, ficando a agência indigenista denominada apenas de Serviço de Proteção aos Índios (SPI)". Esta política de tutela e assimilação distribuía para os indígenas, ferramentas agrícolas, sementes e outros utensílios para a prática da agricultura mecanizada, visando incentivar a produção. Laroque (2007) destaca que durante a primeira metade do século XX este órgão tinha por objetivo primordial evitar os conflitos agrários entre colonos e indígenas que até então eram bastante recorrentes.

O órgão indigenista atuou pouco no Rio Grande do Sul - até 1941 -, ficando sob responsabilidade do próprio estado a administração dos toldos indígenas. É importante assinalar que tal particularidade não evitou o enfrentamento de prejuízos pelos Kaingang, uma vez que, esgotadas as áreas destinadas à colonização nas porções Norte e Noroeste implicou

uma invasão cada vez maior nas reservas, as quais, mesmo legitimadas pelo governo estadual, não possuíam, por parte do mesmo, garantias expressivas de usufruto exclusivo dos indígenas. (BRINGMANN, 2015, p.162)

Este período foi marcado pela pressão de companhias colonizadoras e de alguns políticos que tinham por interesse a redução de terras indígenas, sendo que o governo estadual, em alguns momentos, 
vai agir como incentivador do processo, extinguindo algumas reservas e retalhando outras. Entre os casos de perda territorial em prol da ocupação por colonos, podem ser citadas as áreas de Inhacorá, Nonoai, Votouro e Serrinha. (BRINGMANN, 2015, p.162-163)

É a partir de 1941 que a questão dos indígenas do Rio Grande do Sul passa a ser efetivamente tratada pelo SPI. Apesar de, na teoria, representar a defesa dos interesses dos indígenas, o SPI buscou a inserção dos Kaingang em um modo de vida diferente e interferia na administração das terras demarcadas, aprovando a exploração por arrendatários e madeireiras, excluindo os indígenas na distribuição dos benefícios econômicos provenientes destas práticas.

Ao longo de sua atuação na primeira metade do século $X X$, sua legitimidade foi se desgastando, principalmente, por denúncias de corrupção e atuação fora dos limites impostos pelo governo, através da exploração das riquezas de terras indígenas para enriquecimento particular. Segundo Flores (2017, p.2), em 1963 foi instaurada Comissão Parlamentar de Inquérito (CPI), com o objetivo de

investigar supostas irregularidades cometidas por agentes do Estado brasileiro ligados ao SPI contra populações indígenas na região do Mato Grosso e Amazonas. As denúncias [...] passaram a ser apuradas em todo os Estados do Brasil pelo procurador Jader de Figueiredo Corrêa em uma Comissão de Inquérito em 1967, já no período do regime civil-militar.

O órgão público foi oficialmente extinto em 1967, dando lugar à atual Fundação Nacional do Índio (FUNAI) que passou a atuar nos quesitos de assistência aos povos indígenas, "e em 1968, após a promulgação do Al-5, as investigações são arquivadas" (FLORES, 2017, p.03).

Apesar desta reestruturação governamental no que se refere ao "cuidado" para com as populações nativas do Brasil, não ocorreram mudanças significativas, permanecendo em grande parte a inércia no que concerne ao reconhecimento e à demarcação oficial das terras reivindicadas. Durante este período, intensificaram-se as disputas dentro da esfera governamental entre ruralistas e os povos indígenas que buscavam retornar aos territórios anteriormente ocupados.

No final da década de 1970 inicia-se o que se conhece por reação indígena. Esta reação foi um movimento de retomada de terras empreendido pelos indígenas de todo o Brasil, fazendo parte também, os Kaingang na região sul do Brasil. As ações lideradas por referências como Nelson Xangrê, Ângelo Kretã e outros, visavam, principalmente, expulsar colonos que haviam se instalado dentro das Terras Indígenas, seja por conta própria ou com apoio do Estado. O marco inicial foi o ano de 1978, quando são retomadas porções do Posto Indígena de Nonoai no Rio Grande do Sul e do Rio das Cobras no Paraná, sendo bastante 
representativo nas articulações dos dias atuais que tem por objetivo a reterritorialização. Nas palavras de Danilo Braga (2015)

\begin{abstract}
Depois de recuar, sistematicamente, e perceber que não tinha mais para onde ir, a não ser resistir e salvar os poucos Kaingang que ainda viviam no Estado e mais o resto do espaço que possuíam. Ao perceberem que sua população originária não tinha outra opção, decidiram iniciar uma grande luta, mesmo que isso lhes custasse as suas vidas (BRAGA, 2015, p.75).
\end{abstract}

Com a redemocratização no país após a ditadura civil-militar (19641985), especialmente com a Constituição Cidadã de 1988 que prevê a ampliação de direitos de setores "minoritários", os indígenas Kaingang passaram a adotar uma política cada vez mais sistemática de mobilidade para os centros urbanos. Não defendo a hipótese de que as mobilidades foram fruto ou novidade do período da redemocratização, mas que os movimentos foram facilitados pelo conjunto de leis estabelecido no novo contexto. Desta forma, estes sujeitos saem com maior frequência das áreas oficialmente demarcadas buscando efetivar a ocupação de territórios que pertenciam tradicionalmente a estes e seus antepassados.

Ademais, ao contrário do que muito se escreveu, principalmente pela historiografia do século XIX e início do XX, os Kaingang, por meio dos aldeamentos, não foram absorvidos pela sociedade nacional, abandonando sua cultura e ancestralidade. $O$ pensamento que predominava nesta historiografia era pautado pelo viés eurocêntrico, encontrando como referência histórica os padrões ocidentais. Segundo o antropólogo decolonial, Guillermo Bonfil-Batalla (1990) na obra "México profundo: una civilización negada", que analisa a realidade dos povos indígenas no contexto mexicano e, de alguna maneira, contribui para as discussões do presente artigo, o "Occidente se ve a sí mismo como portador de la civilización universal que, por su carácter único y superior, entraña la negación y la exclusión de cualquier proyecto civilizatorio diferente (BONFIL-BATALLA, 1990, p.234)".

\title{
Aspectos teóricos e metodológicos
}

Os sujeitos indígenas agiam e agem por motivações próprias e mesmo em meio à crise e à exploração que restringiu drasticamente o acesso aos mecanismos de subsistência, acabaram criando formas e desenvolvendo estratégias para manter e/ou ressignificar elementos tradicionais.

Vencidos por la fuerza, los pueblos indios, sin embargo, [...] permanecen como unidades sociales diferenciadas, con una identidad propia que se sustenta en una cultura particular de la que participan exclusivamente los miembros de cada grupo. Casi cinco siglos de dominación, de agresión brutal o sutil contra la cultura 
de los pueblos indios, no han logrado impedir la sobrevivencia histórica [...]. Los caminos de la resistencia forman una intrincada red de estrategias que ocupan un amplio espacio en la cultura y en la vida cotidiana de los pueblos indios (BONFIL-BATALLA, 1990, p.190-191).

Constatada a mobilidade como fator permanente entre os Kaingang, Ribeiro (2013) enfatiza que os "lugares ou cidades preferidos atualmente pelos artesãos são na região noroeste do estado - ljuí, Cruz Alta, Panambi, e da região central - Santa Maria, Santa Cruz - e para Lajeado, na região nordeste do Estado" (RIBEIRO, 2013, p.20). Os Kaingang que residem em Santa Maria ainda mantêm vínculos com os que permaneceram em Guarita, fato confirmado em Perius (2017), que afirma que os indígenas de Três Soitas, por estarem vivendo em ambiente urbano com pouca disponibilidade de matéria-prima, acabam comprando taquaras e cipós dos Kaingang de Guarita para o desenvolvimento do artesanato. Além das relações mantidas pela lógica de comercialização do artesanato, existem os vínculos de parentesco, uma vez que pais e avós dos sujeitos que residem em Santa Maria continuam vivendo na Terra Indígena de Guarita. De acordo com a liderança Kaingang de Três Soitas, alguns parentes vêm de Guarita para comercializar artesanato e durante este período permanecem hospedados na casa do familiar que aqui vive de forma permanente, mantendo as mobilidades no território que são estabelecidas pela ancestralidade e pelos laços de parentesco.

Observando tal processo, estabeleceu-se por objetivo principal analisar a situação do grupo Kaingang residente na Aldeia Três Soitas, tendo como princípio as vindas para Santa Maria para a comercialização do artesanato e a busca por um local permanente em período posterior, enfatizando os aspectos culturais e a organização social na cidade, compreendendo este conjunto de práticas enquanto dinâmicas e inseridas no processo de etnogênese e territorialização a partir das discussões de BARTOLOMÉ (2006), BOCCARA (2005) e PACHECO DE OLIVEIRA (1998).

No que se refere a metodologia utilizada, parte-se do viés qualitativo de análise que segue orientações para o desenvolvimento da pesquisa social, apontando caminhos que possibilitam uma compreensão em rede dos diferentes atores sociais que compõem o contexto analisado. Busca-se, por meio do caráter qualitativo, observar uma multiplicidade de perspectivas para desconstruir parâmetros estanques e artificiais de categorização entre indígenas "aculturados" e "selvagens" presentes na historiografia convencional. Sendo assim, a pesquisa tem o intuito de apresentar uma pluralidade de agentes humanos que se mobilizam de variadas formas sob condições específicas que lhes são apresentadas. A utilização de tais parâmetros segue as ideias de Groulx (2008), que defende o procedimento qualitativo, pois este permite

adquirir uma percepção mais holística dos problemas e das questões, e a proceder a um "reenquadramento socioantropológico", a fim de ter em conta o contexto sociocultural de cada situação-problema e de 
compreender a especificidade e a complexidade dos processos em jogo. (GROULX, 2008, p.97).

A metodologia qualitativa se torna importante ferramenta no reconhecimento de dificuldades pelas quais passam diversos grupos sociais. Esta pode ajudar a pensar formas para o poder público se organizar e agir a fim de combater desigualdades e promover o desenvolvimento social e o respeito pelas diferenças. Nessa percepção aplicada a pessoas pobres, Groulx (2008) afirma que, utilizando-se do estudo qualitativo, é possível compreender estratégias de sobrevivência e pensar políticas de melhoria, podendo ser utilizado também para a situação das mulheres, negros e, no presente caso, dos indígenas Kaingang. Ademais, igualmente pode-se problematizar e buscar a compreensão dos processos que levam determinado grupo às condições nas quais se encontram em dado período do tempo.

A pesquisa qualitativa permite mostrar percepções divergentes através da utilização de fontes de múltiplos suportes, sejam estas escritas ou provenientes da oralidade (entrevistas), tendo validade na apresentação de um conjunto que não separa os aspectos teóricos dos metodológicos, mas criando uma rede integrada. A coleta e cotejamento de informações produzidas tanto pelo Estado e instituições diversas (geralmente de caráter escrito) como pela entrevista de indígenas e nãoindígenas vinculados ao tema, recorrendo à memória (forte presença da oralidade), favorece essa complexificação ao incluir pontos de vista que, se analisados separadamente, poderiam deixar lacunas.

Compreendendo a necessidade cada vez maior da integração entre as áreas científicas, foram levantadas informações tanto de cunho histórico como antropológico e de organização social em contexto histórico recente. Cavalcante (2011), ao trabalhar com a etno-história enquanto método interdisciplinar, contribui positivamente para a pesquisa ao questionar o "fetiche por fontes escritas" e enfatizar a importância que deve ser dada "às tradições orais e às fontes arqueológicas, que podem oferecer dados bastante valiosos sobre essas culturas, as quais, em sua maioria advêm de tradições ágrafas" (CAVALCANTE, 2011, p.359).

$\mathrm{Na}$ questão de fontes escritas foi realizada análise do processo de manutenção/reintegração de posse número 50092819120114047102 com data de autuação em 30 de novembro de 2011 . Este documento trata da tentativa de expulsão dos indígenas Kaingang fixados no acampamento próximo à rodoviária localizada no Largo Irmãos Aita, 1450, Bairro Nossa Senhora de Lourdes. Os documentos relacionados ao processo foram acessados em 12 de junho de 2019 através do portal da Justiça Federal do Rio Grande do Sul. Este conta atualmente com 354 eventos contendo: despachos, decisões, fotografias, petições, intimações, sentença, entre outros. É possível encontrar informações pertinentes a respeito dos pontos de vista de ambas as partes e os níveis de participação de instituições e pessoas.

Também foi efetuada pesquisa no jornal "A Razão" disponibilizado no Arquivo Histórico Municipal de Santa Maria. A escolha do respectivo 
jornal se deu pelo fato deste ser o periódico com maior representatividade local durante o recorte temporal estabelecido, tendo maior potencial informativo sobre o tema da pesquisa. O recorte de tempo tem como marco inicial o ano de 1999, cujo informante Kaingang alega já haver notícias ou informações sobre a presença mais efetiva dos indígenas na cidade até o ano de 2002.

Analisou-se parte das seções do jornal, excluindo-se as páginas de "Esporte", "Classificados" e "Economia', uma vez que, pela consulta inicial, foi constatado um foco divergente da temática e pelo fato de tornar a pesquisa mais eficiente no que tange à otimização do tempo. Os melhores resultados foram encontrados nas abas "Geral", "Resumo" e na página "Polícia". Analisados os quatro anos, ou seja, de 1999 até 2002 obteve-se um total de vinte e oito matérias que tratam desde as formas de subsistência (venda de artesanato), condições de moradia e alimentação, até movimentos de organização em busca de melhorias e reconhecimento de direitos. Após o registro fotográfico, o texto presente em imagem foi transcrito para formato de texto ".doc" do Microsoft Office Word com o objetivo de sistematizar e facilitar o manejo das informações obtidas.

Para além da pesquisa em arquivo, também foi efetuada uma busca por matérias mais recentes sobre o grupo na plataforma "Google", resultando em quatro reportagens de diferentes sites e instituições. As principais são provenientes da Revista "O Viés" e da página da Seção Sindical dos Docentes da UFSM (SEDUFSM), que garantiram maior cobertura, principalmente a partir de 2011, quando os Kaingang passaram a reivindicar fixação permanente na cidade, disputando a mesma pelas vias judiciais.

No que se refere aos subsídios orais, as entrevistas obedecem a algumas orientações básicas de Verena Alberti (2005), principalmente na questão da escolha do indivíduo a ser entrevistado. Segundo a autora "a escolha dos entrevistados não deve ser predominantemente orientada por critérios quantitativos, por uma preocupação com amostragens, e sim a partir da posição do entrevistado no grupo, do significado de sua experiência" (ALBERTI, 2005, p.31).

Para tanto, como entrevistado indígena foi selecionada a liderança, popularmente chamada de cacique, figura representativa dentro do coletivo que é responsável por articulações com instituições públicas e por representar o grupo em mobilizações e eventos educativos, culturais, etc., sendo atribuído, para fins de garantia do anonimato, o pseudônimo "LIDERANÇA KAINGANG". O contato e a respectiva entrevista com a liderança indígena, que foi um dos principais responsáveis pelo processo de ocupação do território em Santa Maria, ocorreu no espaço da Aldeia Três Soitas, acompanhado por observações do meio.

Do indivíduo não-indígena, selecionou-se um informante envolvido com a administração da Casa do Índio - habitação de passagem criada em 2001 para os indígenas que vinham a Santa Maria para comercializar artesanato - sendo chamado de "ENTREVISTADO CASA DO ÍNDIO", ocorrendo a coleta das informações na própria residência. A seleção deste informante foi pertinente para compreender o início da organização dos indígenas sob o ponto de vista "de fora". Em ambos os casos buscou-se 
garantir bem-estar aos entrevistados, facilitando a coleta dos dados. Em etapa anterior à gravação foi lido e apresentado o Termo de Consentimento Livre e Esclarecido (TCLE), firmando o voluntariado e anonimato do(a) entrevistado(a), sendo assinado em duas vias.

Desta maneira, buscou-se, através das entrevistas temáticas (que consideram a participação dos indivíduos entrevistados no tema) e semiestruturadas (com delimitação preestabelecida e possíveis ramificações de acordo com o desenvolver da entrevista), captar as memórias e os pontos de vista dos sujeitos que, por meio do acesso a uma visão própria do processo de etnogênese e reterritorialização, ajudam na compreensão das relações sociais estabelecidas. A reterritorialização é entendida como a busca e ocupação de territórios que são tradicionalmente reconhecidos pelos Kaingang, mas que no passado foram expropriados pelo Estado e particulares durante as políticas de colonização. Estes territórios e seus significados permanecem presentes nas memórias coletivas que, compartilhadas de geração a geração, servem como um importante suporte no reconhecimento da tradicionalidade e das relações simbólicas estabelecidas no passado e no presente. Os depoimentos orais utilizados no que se refere ao estudo dos Kaingang "podem servir não apenas a objetivos acadêmicos, como também constituir-se em instrumentos de construção de identidade e de transformação social" (FERREIRA, 2002, p.327). É através de um comparativo entre as fontes provenientes de locais de fala diversos que se constrói uma visão mais ampla e complexa, percebendo as diferentes interpretações sobre a temática.

Por fim, tem-se por intuito compor um conjunto documental diversificado e amplo para perceber os jogos de interesse na inserção dos indígenas Kaingang na sociedade urbana santa-mariense, nos quais os movimentos sociais ganham maior visibilidade. Partindo de discussões estabelecidas a partir da Nova História Indígena é possível pensar novas abordagens que consideram os indígenas enquanto protagonistas e capazes de fornecer informações válidas a respeito do passado para as pesquisas históricas.

A perspectiva da Nova História Indígena tem como base fundamental o reconhecimento dos indígenas enquanto sujeitos que agem de acordo com interesses próprios e não como meros expectadores do processo histórico.

Si la violencia ha sido el instrumento de la dominación, los pueblos indios también han recurrido a ella para rechazar la sujeción y reivindicar la libertad. La historia registra una cadena incesante de guerras de defensa ante la invasión y de sublevaciones contra la opresión colonial, que dan cuenta de la no-conquista, de la rebeldía y la afirmación historica de los pueblos indios y su voluntad de permanencia (BONFIL-BATALLA, 1990, p.187-188).

Bonfil-Batalla (1990), apesar de tratar de realidades específicas dos povos indígenas do México, pode facilitar a compreensão de situações 
semelhantes de outras regiões do continente americano. Problemáticas como a negação das culturas indígenas pela memória nacional, o suposto desaparecimento identitário frente à conquista e as formas de organização mantidas e/ou reelaboradas por estes sujeitos históricos durante a colonização, demonstram a importância da análise sob um ponto de vista que valoriza a atuação dos indígenas no processo histórico.

Tem-se nesta linha historiográfica uma forma de conciliar tanto a utilização diversificada de fontes, garantidas pela metodologia qualitativa e a etno-histórica, como perceber a presença dos Kaingang em ambiente urbano, não como um elemento que corrobora uma suposta destruição identitária, mas como um mecanismo adotado na busca por melhores condições de vida e reconhecimento. Através desta forma de interpretar, dá-se ênfase ao caráter dinâmico das culturas, apontando para transformações ocorridas no ambiente, principalmente com os aldeamentos e o contato com colonizadores, e as maneiras de se reorganizar por parte dos indígenas de acordo com as novas possibilidades.

A Nova História Indígena estabelece as estruturas do desenvolvimento da pesquisa através de diferentes fontes históricas, sendo a memória um destes aportes para a elaboração de problemáticas e conclusões. A voz silenciada pelo discurso oficial pode vir a receber espaço no estudo de informações orais, portadoras de importante valor social e de reconhecimento identitário para as ditas "minorias".

Buscando compreender as territorialidades Kaingang no Rio Grande do Sul em um contexto temporal recente - a partir da redemocratização em 1985 -, especialmente quando se trata da presença destes indígenas na cidade de Santa Maria a partir de 1999, tem-se como princípio de análise um conjunto de fatores que ajuda a compreender estas novas distribuições espaciais e as mudanças histórico-culturais decorrentes. São problemáticas as situações que se consolidam por meio da circulação destes indivíduos em espaços urbanos e as ressignificações adotadas no que se refere às práticas cotidianas.

\section{Territorialidade Kaingang}

Com o intuito de fundamentar o estudo deste processo de busca por territórios considerados tradicionais dos Kaingang em tempos recentes, são apresentados como eixos norteadores vários elementos, elencando a formação das chamadas aldeias urbanas (elemento novo e que gera discussões complexas a respeito da etnicidade e cultura Kaingang), a reivindicação de direitos presentes na Constituição Federal de 1988 potencializadas pela autodeterminação, e as mudanças interpretativas a respeito do tempo e espaço por parte dos próprios indígenas, inseridas no caráter dinâmico das culturas. Levar em consideração os aspectos supramencionados possibilita compreender a atuação destes sujeitos embasados em novas estratégias de organização não mais restritas às práticas puramente tradicionais de manutenção da 
cultura, mas em um movimento que é resultado do contexto historicamente transformado no qual estes sujeitos passam a atuar.

Para o princípio da discussão é importante falar sobre os contatos dos indígenas com os colonizadores, apontando as rupturas nas condições de organização social e cultural decorrentes deste processo. Apesar de trazer uma concepção ativa dos indígenas, não podem ser negadas as consequências decorrentes do contato e das práticas do Estado a partir do século XIX, que resultou em uma agressiva redução das terras tradicionais então ocupadas. González Casanova (2007), a fim de compreender esse mecanismo de expropriação de terras e trazendo a problemática para o contexto atual, demonstra que a ideia de colonialismo está longe de ser uma situação do passado. Ademais, é perceptível a existência, dentro do âmbito nacional, de um sistema de exploração exercido por um grupo social privilegiado em relação a outros, justificando este como meio para se chegar ao progresso. São elencadas pelo autor sete principais características demonstrando quando está presente o colonialismo interno, ou seja, quando no Estado nacional existem grupos cujos

1) habitam em um território sem governo próprio; 2) encontram-se em situação de desigualdade frente às elites das etnias dominantes $[\ldots]$; 3) sua administração e responsabilidade jurídico-política concernem às etnias dominantes, às burguesias e oligarquias do governo central $[\ldots]$; 4) seus habitantes não participam dos mais altos cargos políticos e militares do governo central, salvo em condição de "assimilados"; 5) os direitos de seus habitantes, sua situação econômica, política social e cultural são regulados e impostos pelo governo central; 6) em geral [...] pertencem a uma "raça" distinta da que domina o governo nacional e que é considerada "inferior" $[\ldots]$; 7) a maioria dos colonizados pertence a uma cultura distinta e não fala a língua "nacional". (GONZÁLEZ CASANOVA, 2007, p.02)

No século XIX o Império brasileiro passou a adotar políticas de incentivo à imigração, principalmente de alemães e italianos, a partir de 1824 e 1875 respectivamente. Estes vinham para o Brasil em busca de melhores condições de vida, incentivados pelo Império para "povoar espaços vazios" da Província de São Pedro, garantindo, assim, a sua posse em relação aos castelhanos e o fornecimento de alimentos para as cidades mais populosas, como Porto Alegre. A chegada destas famílias da Europa, juntamente com a criação dos aldeamentos, fez com que os Kaingang se deparassem com uma série de mudanças que implicaram transformações no ambiente onde viviam. Estes, a partir de então, criaram ressignificações a respeito do espaço tradicionalmente ocupado e das maneiras de se articular dentro dele, buscando garantir a sobrevivência e reduzir os danos.

O território para os Kaingang possui grande relevância, uma vez que não se restringe ao caráter puramente produtivo/material da terra, 
como uma simples ferramenta a partir da busca pelo lucro, mas estabelece as raízes desempenhadas pelas memórias coletivas pelas quais os Kaingang da atualidade se ligam aos antepassados que ali viveram.

Os indígenas veem na terra algo muito mais do que um simples espaço econômico, como o é para o modo capitalista de exploração. A terra para eles representa a base da vida social, suas raízes, e não apenas serve para a subsistência das comunidades e está diretamente ligada ao cotidiano como um todo interligado. (GARLET, 2010, p.113)

Isto pode ser identificado na entrevista com o representante dos Kaingang, acrescentando o caráter compartilhado entre a terra tradicional e as gerações que com ela se relacionam quando se referem à terra enquanto "Mãe". Através do compartilhamento de elementos da cultura Kaingang, conhecimentos e o reconhecimento de símbolos ancestrais transmitidos pela oralidade, geralmente atributo das pessoas mais velhas do coletivo, é que são construídas as pautas de mobilização em busca da ocupação destes espaços. É pertinente destacar a inserção dos indivíduos no espaço e das relações estabelecidas com ele:

Para os Kaingang, seus territórios representam um suporte identitário, pois ele não representa apenas uma porção do espaço politicamente delimitado e com fronteiras estanques, mas um espaço permeado de símbolos e significações pertinentes às coletividades. (LAPPE, 2015, p.42)

A liderança Kaingang, ao ser questionada a respeito destas relações com o território e das práticas simbólicas a elas inerentes, descreve algumas situações a respeito das viagens que eram feitas pelos Kaingang para fora das Terras Indígenas. Na maior parte dos casos, o destino era a capital Porto Alegre, onde buscavam reivindicar melhorias para os Postos Indígenas e o respeito de seus limites, sendo que nestes caminhos eram enterrados os umbigos de crianças recém-nascidas, maneira esta, "de demarcar o território e para que elas tenham saúde [...]; portanto, são ações possuidoras de forte caráter simbólico com o território" (LAPPE; LAROQUE, 2015, p.152). Na entrevista destaca-se que

Como as viagens eram longas e duravam meses [...] crianças nasciam nas viagens [...] e, isso é real, nós do povo Kaingang, nós plantamos o umbigo da criança onde ela nasce. [...] eu não nasci aqui, mas as nossas gerações passadas nasceram por aqui. [...] meus avós [...] eles nasceram já fazendo essa viagem, essa rota deles [...] fora do Guarita. (ENTREVISTADO INDÍGENA, 2019) 
Os diferentes grupos étnicos não se mantêm estáticos dentro da linha temporal, uma vez que até mesmo isentos de contato com outros, sofrem modificações e/ou criam ressignificações na busca por sua continuidade existencial no mundo. Buscando embasar conceitualmente os grupos étnicos, utilizo como referência as afirmativas de Linares (2015), observando importâncias variadas na constituição de categorias ditas étnicas.

Las categorías con que se clasifica y distingue a los grupos humanos diferentes en cada sociedad constituyen un conglomerado complejo de elementos dispares y heterogéneos. Estas "constelaciones étnicas" son particulares de cada contexto histórico y social. En algunos casos una dimensión supuestamente biológica recibe particular énfasis, aunque siempre es interpretada y resignificada social y culturalmente; en otros contextos, priman los factores culturales o geográficos; en otros más se da una mayor importancia a la autoadscripción. (LINARES, 2015. p. 90)

Com a redução dos territórios tradicionais no atual Rio Grande do Sul, intensificada pela política de aldeamentos e exploração das terras demarcadas por particulares, tanto no período imperial como republicano, os Kaingang se reorganizaram e passaram a atuar dentro das novas possibilidades que Ihes foram apresentadas. Uma situação que passou a ser recorrente, mas que não era novidade, foi a visita de lideranças em cidades maiores, principalmente na capital Porto Alegre, buscando contatar as lideranças governamentais para reivindicar melhorias nos aldeamentos, tornando possível afirmar que as mobilidades indígenas para as cidades não são acontecimentos recentes, mas que já aconteciam desde a segunda metade do século XIX no Brasil Império, perpassando a Primeira República e chegando aos dias atuais.

Mesmo com os indígenas aceitando o aldeamento, não se pode afirmar de maneira simplista que estes agiram passivamente aceitando as imposições do Estado. Nonnenmacher (2000) afirma que, de maneira geral, os Kaingang perceberam na prática de aldear uma maneira de garantir, mesmo que de forma reduzida, o acesso à terra e a segurança da população.

A respeito da redução territorial indígena, são apresentados dois conceitos fundamentais, a fim de facilitar a compreensão desta trama de reorganização dos grupos sociais na terra e as representações que os atores envolvidos têm sobre ela. Com este fim referencia-se o trabalho de Tommasino e Almeida (2014), que aborda a situação da expropriação territorial no Estado do Paraná, indicando uma oposição entre Terra Indígena e Terra Tradicional ou Ngá. De um lado, o Estado e os sujeitos que nele operam com seu próprio ponto de vista, impõem os limites entre o que é ou não pertencente aos indígenas por meio da criação do conceito de Terra Indígena. Para estes autores tal categoria tem caráter jurídico e legal e serve para designar 
uma área de terra delimitada e homologada pelo poder público. [...] as atuais Terras Indígenas no Paraná correspondem a uma ínfima parte das "terras tradicionalmente ocupadas pelos índios" de que fala a Constituição Federal". (TOMMASINO; ALMEIDA, 2014, p.31)

Em contrapartida, inserindo a problemática da terra nas discussões teóricas da Nova História Indígena, é pertinente levar em consideração o que e como pensam os Kaingang. Estes, com referências à memória e à tradição oral (característica bastante presente em culturas indígenas), defendem um viés que destoa da concepção oficial, através do termo Terra Tradicional Kaingang ou Ngá.

A Ngá corresponde à área onde os Kaingang sobrevivem e exercem suas territorialidades. Inclui a área da Terra Indígena mais as áreas do entorno que eram parte de seus territórios tradicionais - de forma que eles nelas se mantiveram (mesmo que na condição de frequentadores temporários). (TOMMASINO; ALMEIDA, 2014, p.31)

O conceito de Terra Tradicional Kaingang elucida que mesmo não frequentando estas áreas ou permanecendo nestas somente por determinado espaço de tempo, os Kaingang mantêm vínculos, inclusive, destacados pela memória coletiva (recurso básico a ser utilizado para a obtenção de dados sobre a trajetória do grupo). Segundo informações do entrevistado indígena "a nossa ligação com o espaço, com a terra, com a nossa mãe-terra, isso é de geração em geração. Nós nascemos com isso" (LIDERANÇA KAINGANG, 2019). Tal declaração demonstra para o não abandono das "raízes" da etnia em relação aos espaços ocupados em tempos ancestrais. Os Kaingang no Rio Grande do Sul passaram por um "efeito sanfona", de redução seguida por uma reocupação de territórios e que as fronteiras estabelecidas por estes agentes históricos vão muito além daqueles limites estabelecidos pelo Estado Nação.

Mesmo existindo um conjunto de leis, tais como a Constituição Federal de 1988 e a Convenção nº169 da Organização Internacional do Trabalho (OIT), que visam garantir o acesso e direito dos povos indígenas à terra, é sabido que historicamente estes passaram por diversas expropriações representadas pela criação dos aldeamentos, demarcação, loteamento e venda de terras consideradas devolutas e disputas com colonos, tendo seus territórios reduzidos consideravelmente, acarrentando dificuldades de sobrevivência física e cultural. Em meio às interferências resultantes do processo colonizador e mesmo tendo conquistado áreas através da cobrança da lei, algumas Terras Indígenas acabam se tornando insuficientes devido ao crescimento demográfico que se acentua cada vez mais. Segundo informações obtidas através de entrevista, fica evidente esta situação, uma vez que o informante enfatiza a ação desempenhada pelo cacique Fongue do aldeamento de Guarita quando de sua demarcação, sendo que este buscava ampliar ao máximo a extensão territorial pensando no aumento populacional do futuro. 
O cacique Fongue lutou por um espaço, pensando em todos, que com o passar do tempo, o número de indígenas ia aumentar [...] na prática ao invés de acontecer no original, diminuiu. Até hoje, [...] indígenas do Guarita [...] sabem onde é que passa a divisa, onde o cacique Fongue pediu que fosse demarcado. (LIDERANÇA KAINGANG, 2019)

Neste momento é interessante perceber a presença da memória a respeito de situações vividas há várias décadas pelo povo Kaingang e que são compartilhadas através da oralidade. O informante relata de forma convicta e repete na entrevista que "até hoje eles sabem disso", demonstrando o quanto a trajetória de luta perdura dentro do universo simbólico e de rememoração dos Kaingang no que se refere à luta pela terra.

Devido às constantes transformações a nível estrutural da sociedade e das condições que abrangem as formas de vida dos Kaingang, a reterritorialização em diversos casos extrapola inclusive o fator ambiental, tendo a presença cada vez mais significativa destes no meio urbano. Com a organização e desenvolvimento do Brasil enquanto nação capitalista, as formas de sustento econômico que partem das bases tradicionais da caça, da pesca e de outras atividades relacionadas encontram cada vez mais desafios para serem mantidas. O ambiente transformado historicamente principalmente pela ação dos colonizadores que abriam roçados em áreas anteriormente marcadas pela predominância do mato, fez com que estas práticas sofressem transformações, como é o caso do artesanato.

Para fins norteadores, ao falar a respeito do conceito de reterritorialização, utilizo como referência a obra de João Pacheco de Oliveira (1998). Para o autor

a noção de territorialização é definida como um processo de reorganização social que implica: 1) a criação de uma nova unidade sociocultural mediante o estabelecimento de uma identidade étnica diferenciadora; 2) a constituição de mecanismos políticos especializados; 3) a redefinição do controle social sobre os recursos ambientais; 4) a reelaboração da cultura e da relação com o passado. (PACHECO DE OLIVEIRA, 1998, p.55)

No que se refere às quatro situações acima elencadas, pelo menos três podem ser relacionadas com resultados obtidos a partir do estudo da Aldeia Três Soitas em Santa Maria. A constituição de mecanismos políticos especializados pode ser percebida através da atuação cada vez mais efetiva de indígenas nos próprios aparelhos administrativos do Estado, na inserção de sujeitos no ambiente da política e na educação, seja pela realização de palestras em Universidades ou na própria educação escolar bilíngue garantida legalmente pela Constituição de 1988. O que muitas vezes pode parecer uma "assimilação" destes 
indivíduos pela sociedade, nada mais é do que uma estratégia adotada visando ampliar os campos de reivindicação de direitos. Com relação a esta prática, o informante indígena afirma sobre as gerações atuais dos Kaingang que se busca

formar pessoas $[\ldots]$ através da educação, fazendo com que a gente reconheça cada vez mais daquilo que é do nosso direito $[\ldots]$ tem nascido nessa geração nova nossa, guerreiros que vêm lutar por nós, principalmente para trabalhar com a burocracia do próprio Estado. Então é bem interessante isso [...] de ver os nossos filhos se engajando nessa luta por espaço que é nosso, dos territórios tradicionais (LIDERANÇA KAINGANG, 2019).

A respeito do controle de recursos naturais e da reelaboração de seu manejo, inclui-se nesta problemática a ocupação de áreas em meio urbano, criando mecanismos para acessar matérias-primas utilizadas principalmente na fabricação do artesanato. Tem-se, como exemplo, o caso relatado por Perius (2017), que aborda os sistemas de coleta de chás, cipós e taquaras em áreas particulares e a obtenção destes produtos pelos indígenas de Santa Maria junto aos Kaingang de Guarita. O comércio do artesanato, enquanto saída para as dificuldades de abastecimento e sustento, tem como base essencial os núcleos urbanos, uma vez que é nestes aglomerados humanos em que a troca e venda de produtos se torna mais efetiva. É válido entender que a comercialização do artesanato passa a se inserir no âmbito capitalista, implicando a busca por centros com maior concentração populacional, o que significa um potencial mercado consumidor.

em todo o lugar que eu for, a renda familiar é o artesanato. Aqui [...] $99 \%$ da renda familiar vem do artesanato. A gente está numa cidade grande, está lutando por um espaço [...] não só em feiras anuais, até nós pedimos [...] de nós participarmos do evento no município. A gente sabe que acontecem diversos eventos no ano que o município organiza, [...] patrocina, apoia (LIDERANÇA KAINGANG, 2019).

Desta forma, os Kaingang exercem a retomada de territórios tradicionais e, muitas vezes, decidem por fixar-se nas cidades ou próximo destas, reivindicando o reconhecimento permanente de ocupação, a fim de alcançar uma melhor qualidade de vida, como é o caso de Três Soitas e, também, das terras indígenas Foxá e Por Fi Gâ nos contextos urbanos dos rios Taquari-Antas e Sinos pesquisados por Emeli Lappe (2015) que se assemelha ao presente estudo.

Partindo deste princípio e analisando as afirmativas de Kimmie Tommasino e Ledson Almeida (2014), os Kaingang passam a atuar com novos parâmetros, ou seja, a quarta situação apontada por Pacheco de Oliveira (1998), buscando reocupar antigos espaços que foram transformados. Tommasino e Almeida explicam essa reestruturação 
organizacional a partir da diferenciação do tempo em duas situações, o vãsy e o uri: "os Kaingang classificam o tempo antigo [...] como vãsy. Trata-se de um tempo onde viviam da caça, pesca e coleta e tinham territórios imensos e repletos de alimentos" (TOMMASINO; ALMEIDA, 2014 , p.22). Já o uri é aquele constituído como consequência da redução das áreas de ocupação indígena e a exploração dos espaços tradicionais por colonizadores apoiados pelo Estado, seguido de sua degradação a partir de práticas como o arrendamento e a extração de madeira para lucro de particulares.

No uri, os Kaingang buscam novos meios e espaços para manterem sua cultura. Neste modelo de interpretação do tempo e do mundo, os Kaingang buscam cada vez mais a atuação em contextos urbanos, tendo como principal fonte econômica a comercialização de artesanato. Um modelo é a dissertação de mestrado de Lappe (2015), que trata das terras indígenas em cidades nas regiões dos rios Taquari-Antas e Sinos e que se assemelha muito com o processo pelo qual passaram/passam os Kaingang de Três Soitas em Santa Maria.

Sendo assim, o uri se forma com as espacialidades territoriais, ou seja,

a demarcação propriamente do espaço físico, histórico envolvendo a legalização das Terras Indígenas nas cidades e a nominação dessas Terras Indígenas" e também "as movimentações pelos tradicionais territórios e o estabelecimento destes indígenas em contextos urbanos. (LAPPE, 2015, p.22)

Estas mudanças, que acabam implicando a fixação dos Kaingang em ambientes urbanos, são claramente definidas pela liderança quando relatam as dificuldades encontradas nas Terras Indígenas demarcadas e as mudanças nas condições para viver seguindo as formas tradicionais Kaingang. Segundo o informante indígena,

tem atualmente várias terras demarcadas do nosso povo Kaingang, localizadas em vários municípios do Estado. Mas [...] não é porque tem uma aldeia, uma terra demarcada que também há condição de vida, de criar teus filhos, de sustentar tua família [...] nós indígenas, no espaço que a gente ocupa, planta para consumo próprio, mas muitas das vezes falta esse incentivo do próprio Estado brasileiro, a nós continuar com nossa cultura [...] Muitas vezes a gente opta por sair de uma aldeia e viver perto de uma cidade. (LIDERANÇA KAINGANG, 2019)

As mobilidades Kaingang possuem fatores que são determinantes, como é o caso da mudança nas condições de suprimento de necessidades básicas e tradicionais, implicadas pelo processo de deterioração acelerado do meio, consequência direta das práticas colonizadoras que levaram os indígenas a buscar novas formas de subsistência. Estas 
mudanças podem ser as causadoras do surgimento da diferenciação dos tempos vãsy e uri: "o mato que tinha não é mais aquele de cem, cento e cinquenta, duzentos anos atrás, não é mais. Então, a gente opta por [...] viver perto da cidade pra buscar condições melhores pra [...] comunidade" (LIDERANÇA KAINGANG, 2019). É importante assinalar que o tempo para os Kaingang não é compreendido a partir de uma concepção linear, acarrentando uma sucessão e consequente substituição dos tempos, marcados pelo fim de um e início do outro em um ano específico. A distinção entre estes dois tempos possui como base as condições (naturais, sociais, políticas, etc.) do momento em que se vive, podendo haver a concomitância destes em determinados período. Por exemplo, quando se vai ao mato para coletar recursos destinados à confecção dos balaios encontram-se características do vãsy, mas ao ir para os centros urbanos vender o produto se vive de acordo com situações do uri.

Outro fator, não menos importante, trata das possibilidades criadas a partir do contexto social e jurídico que reconhece os direitos à terra e às diferenças, garantidos com a Constituição de 1988, assim como a autodeterminação defendida pela Declaração das Nações Unidas sobre os Direitos dos Povos Indígenas.

o contexto histórico dos Kaingang e da legislação que passou a vigorar a partir do final dos anos 1980, temos, nas últimas décadas do século $\mathrm{XX}$, uma intensa movimentação de famílias Kaingang em contextos urbanos do Rio Grande do Sul, a fim de procurar sobrevivência física e cultural. Mesmo fazendo movimentações sistemáticas de um território para outro, questões relacionadas à memória são as motivações para esses deslocamentos. (LAPPE, 2015, p.19)

O princípio da autodeterminação, ou seja, a garantia afirmada aos indígenas de viverem de forma diferenciada, de acordo com seus padrões culturais e de organização social, torna-se importante fator no reconhecimento identitário, especialmente quando fora de terras demarcadas. Tal pressuposto foi primeiramente defendido na Convenção 169 da OIT realizada em 1989 em Genebra. No Brasil, o processo de aprovação foi bastante demorado, tendo sido assinado o Projeto de Decreto Legislativo pelo Executivo em 1991, passando pela Câmara dos Deputados em 1993 e ficando sob avaliação do Senado até 2002.

\section{Aldeia Três Soitas: etnogênese em Santa Maria}

Ampliando o contexto de análise e comparando com o trabalho de Lappe (2015), pode-se afirmar que essa reocupação de territórios não ocorre de forma isolada em Santa Maria. Diversos são os estudos que tratam desta perspectiva e com outros grupos em outras cidades. A autora destaca que existem atualmente no Estado do Rio Grande do Sul, além da Aldeia Três Soitas, outras oito aldeias Kaingang no meio urbano. 
Três delas estão na cidade de Porto Alegre, que são as Terras Indígenas Morro do Osso, Morro Santana e Lomba do Pinheiro; uma na Serra Gaúcha: Pó Nãnh Mág, na cidade de Farroupilha; uma no vale do Sinos: Por Fi Gâ, na cidade de São Leopoldo; e três no vale do Taquari, que são as terras indígenas PóMỹg, em Tabaí, Jamã Tÿ Tãnh, em Estrela, e Foxá, em Lajeado (LAPPE, 2015, p.19).

A formação da Aldeia Três Soitas deve ser analisada enquanto processo, pois não ocorreu "da noite para o dia". Os Kaingang passaram a frequentar o território e suas proximidades buscando legitimidade de ocupação já no ano de 1999. A ocupação dos Kaingang na região que corresponde ao atual município de Santa Maria é de tempos anteriores à chegada dos ibéricos na América. Tal informação é encontrada em diversos autores quando estes abordam a questão da distribuição espacial através da delimitação por bacias hidrográficas. Segundo Becker (1976) e Laroque (2007), o rio Jacuí, tendo como afluente o Vacacaí-Mirim, que passa por Santa Maria na Depressão Central do Rio Grande do Sul, é um dos delimitadores das territorialidades tradicionais Kaingang.

Considerando-se as regiões fisiográficas do Rio Grande do Sul, a área Kaingang abrange: Litoral (norte), Campos de Cima da Serra, Encosta inferior e superior do Nordeste, Planalto médio, Alto Uruguai, Missões e Depressão Central, ocupando sempre as áreas mais altas. (BECKER, 1976, p.33)

Os movimentos de ocupação dos territórios Kaingang não se tratam de eventos isolados decorrentes da atualidade, mas que se espelham em práticas adotadas já pelos antepassados no início do processo de colonização e contato, buscando através de articulações e visitas aos centros urbanos, requerer, frente aos responsáveis pela administração, melhores condições para as famílias que habitavam territórios delimitados pelo Estado. É característica da dinâmica Kaingang a contração de alianças com o poder público, estendendo-se temporalmente desde o século XIX até os dias atuais, tendo como exemplo o caso da presença de famílias Kaingang e Guarani na cidade de Santa Maria e em outros municípios do Estado.

Através da pesquisa realizada no jornal "A Razão" a partir de janeiro de 1999, foram constatados os chamados acampamentos provisórios ou Wãre, confirmando a informação obtida em trabalho de campo. Porém, como já esclarecido, a ocupação deste espaço tradicional urbano é de caráter lento, gradual e provisório em seu início, com diferentes indivíduos e famílias que se alternavam, garantindo uma ocupação permanente do espaço pela etnia, mesmo que não pelos mesmos indivíduos. A fonte indígena entrevistada afirma que a ocupação "permanente na cidade de Santa Maria é desde o ano de 1999. [...] a gente já vem ocupar esses espaços [...] na cidade de Santa Maria [...], assim, se trocando (LIDERANÇA KAINGANG, 2019)". 
A fim de garantir o espaço, os sujeitos foram se "trocando", isto é, se alternando. Enquanto um grupo permanecia em Santa Maria fabricando e vendendo o artesanato, o outro retornava para a Terra Indígena de origem ou acabava indo para outra cidade, demonstrando uma certa mobilidade no território reconhecido por estes como tradicional.

Reconhecendo a identidade indígena destes sujeitos que saem das terras demarcadas pelo governo já desde o Império, buscando viver mesmo que nas cidades no contexto recente, é que se aplica o conceito de etnogênese, ou seja, partir de uma análise que leva em consideração não somente a presença e manutenção de elementos culturais do passado, mas, também, a participação e a implicação de situações que são geradas ao longo do processo histórico de colonização e reconhecimento de direitos nos dias de hoje, possibilitando, assim, uma percepção histórica do grupo Kaingang no que tange ao reconhecimento cultural e identitário indígena. Neste sentido, ocorre a interligação de diversos fatores no que tange à reivindicação de identidade, mesmo que modificada em situações do presente.

Pacheco de Oliveira (1998) inclui nesta discussão a importância das relações estabelecidas entre os sujeitos que reelaboram sua identidade a partir do contato com outros grupos indígenas com o objetivo de se diferenciar da categoria generalizante atribuída ao termo "índios".

As afinidades culturais ou lingüísticas, bem como os vínculos afetivos e históricos porventura existentes entre os membros [...] serão retrabalhados pelos próprios sujeitos em um contexto histórico determinado e contrastados com características atribuídas aos membros de outras unidades, deflagrando um processo de reorganização sociocultural de amplas proporções. (PACHECO DE OLIVEIRA, 1998, p.56)

Segundo Boccara (2005), a análise da constituição das identidades indígenas, a fim de englobar um ponto de vista mais complexo, parte de parâmetros da etnogênese, estabelecendo vínculos entre características específicas de cada grupo que se identifica com um passado comum, mas que, ao mesmo tempo encontra-se inserido em um contexto social, econômico e cultural modificado. As interpretações que levam em consideração somente o estudo de elementos ditos tradicionais podem apresentar alguns problemas, como, por exemplo, a aplicação de um viés essencialista e não histórico (estático), negando o direito ou a condição de cultura dinâmica que se modifica de acordo com interações estabelecidas historicamente, seja de maneira violenta e hostil ou de transformações propositais e independentes, dadas a partir do contato:

las aproximaciones en términos de mestizaje, etnogénesis y etnificación representan [...] un aporte real a la producción de un nuevo conocimiento etnológico y etnohistórico pues, además de permitirnos ir más allá de la dicotomía resistencia/aculturación, dejan definitivamente atrás la perspectiva arcaizante sobre las 
sociedades indígenas y su devenir histórico. (BOCCARA, 2005, p.44)

Ao ressaltar a etnogênese enquanto processo histórico, Bartolomé (2006) assinala um desafio que parte da desconstrução do amálgama de culturas estabelecido pela ideia de identidade nacional homogênea. Porém, é perceptível que, para de ampliar o alcance das reivindicações e garantias legais, alguns grupos indígenas criam uma certa unidade para fins de legitimidade e reconhecimento perante a sociedade. A respeito disso, o entrevistado indígena, quando perguntado se estava em Santa Maria no início da ocupação, responde: "Não, em 99 eu não estava ali. Estavam outras famílias. Eram Kaingang. E como é hoje? Não são as famílias de 1999? Mas a comunidade é a mesma" (LIDERANÇA KAINGANG, 2019). Em outro trecho da entrevista, o informante ainda destaca:

o Kaingang é um povo. [...] hoje eu estou aqui, mas amanhã eu posso estar em outro lugar, em uma outra cidade, em uma outra aldeia. Sendo Kaingang, aquela aldeia é minha. [...]. Começaram a nos dividir, nos tirar de um lugar e colocar em outro, quem fez isso com nós foi o próprio estado brasileiro. [...] em questão de luta [...] a gente tem feito a luta em conjunto, principalmente com a ocupação tradicional dos espaços nossos. (LIDERANÇA KAINGANG, 2019)

Há diferentes formas de identificação e reconhecimento de indivíduos em relação à sua etnia. O processo de etnogênese geralmente possui amplas ligações com elementos característicos da cultura ancestral (cosmovisão, representações, rituais, valores, hábitos e códigos culturais), criando um enraizamento do presente para com o passado, ao mesmo tempo em que busca na memória um sistema capaz de armazenar e difundir a trajetória do grupo no espaço e no tempo:

as relações das comunidades atuais com as do passado produzem-se por meio da seleção e da recriação de aspectos da memória e de traços culturais emblemáticos, capazes de atuarem como sinais externos de reconhecimento entre aquelas instâncias de poder que declararam sua extinção. (BARTOLOMÉ, 2006, p.4950)

Ainda neste sentido, existe por trás das etnogêneses um conjunto legislativo capaz de legitimar as reivindicações por identidade e território. Bartolomé (2006) afirma que não se deve cometer o equívoco de pensar estes grupos como que gerados espontaneamente somente pelas leis, mas que estes existiam e ocupavam espaços na sociedade, sendo vistos como estigmatizados ou tendo sua identidade negada pelos demais setores.

Os indígenas Kaingang, ao buscarem a reestruturação de símbolos compartilhados delimitadores de sua etnicidade, assim como, ao 
reconhecerem as mudanças nas condições sociais e ambientais ocasionadas pela ação colonizadora, passam a frequentar lugares diferenciados em busca de uma ampliação de suas vozes. A ocupação e utilização de mecanismos, mesmo que não os tidos como tradicionais, torna-se central na etnogênese, uma vez que possibilita, além do fim instrumental para obtenção de recursos (dos mais variados tipos), uma forma de reconhecimento e a produção de uma dinâmica social capaz de mobilizar a coletividade em torno de ações conjuntas, não deslegitimando suas formas de agir e de se organizar. Bartolomé (2006) aborda situações relacionadas à escrita, que é transformada em ferramenta para a busca de melhorias nas condições de vida e na construção de uma identidade comum: "o processo de construção ou reconstrução identitária supõe assim um nível de reflexividade coletiva orientada para a valorização da história e da cultura compartilhada, em alguns casos mediada pela escrita" (BARTOLOMÉ, 2006, p.58).

A redução territorial, implicada pelos aldeamentos e o gradativo aumento demográfico dentro de seus limites, fez com que muitos Kaingang buscassem novas formas de subsistência. Assim, ocorreram e ocorrem as visitas indígenas em cidades, tanto na região onde estão situadas as Terras Indígenas, como em territórios reconhecidos pela memória como tradicionais. Nestas visitas, a principal fonte de renda é obtida através da venda do artesanato, que passa a ocupar espaço central no novo meio, não somente como elemento da cultura Kaingang, mas também uma forma de subsistência.

A mobilidade e a presença dos Kaingang no espaço urbano de Santa Maria podem ser percebidas na reportagem do jornal "A Razão" de 20 de abril de 1999. Ela trata da Kaingang Santa Pinto, que teria vindo à cidade com mais outros onze familiares para vender artesanato: "a kaingang lembra que desde pequena era carregada pelos pais de uma cidade para outra, assim, ela se acostumou a viver fora da aldeia" (BORELLI, 1999, p.07). Logo, percebe-se que esta prática já era adotada antes mesmo da redemocratização e, por meio da reportagem, conclui-se, também, a importância atribuída pelos Kaingang à convivência das crianças com os adultos, principalmente nas relações sociais dadas desde 0 acompanhamento nas viagens para cidades, visando a comercialização do artesanato.

Analisando as características da ocupação Kaingang em Santa Maria, percebe-se um grau representativo de semelhança ao processo que é descrito por Lappe (2015) ao trabalhar com os Kaingang em Lajeado, enfatizando um período em comum para a busca por territórios tradicionais de forma mais significativa (no caso, final de 1999 e início de 2000), assim como os lugares onde estes erguiam acampamento (áreas próximas de rodoviárias). A reportagem menciona as dificuldades encontradas pelo coletivo, principalmente nos quesitos alimentação e moradia, pelo fato de morarem sob barracos de lona sem consumir carne há três dias, mantendo uma dieta à base de pipoca e leite.

No ano de 2000, encontram-se reportagens que tratam da mobilidade que vinha sendo estabelecida através do revezamento enquanto forma de garantir o espaço. A maioria, proveniente da Terra 
Indígena do Guarita, passa a manter o acampamento em um terreno baldio próximo ao terminal rodoviário de Santa Maria, local onde fixaram residência até o início de 2019 , sendo de lá transferidos para a área rural.

Cerca de 19 índios da tribo caingangue, da reserva de Guarita, em Tenente Portela estão em Santa Maria. Eles chegaram na tarde de terça-feira e não tem onde se instalar. Os adultos que vieram, em torno de seis, trouxeram artesanato, cestos e ervas medicinais para vender pela cidade. Instalados provisoriamente no Albergue municipal, os índios agora ocupam um terreno baldio próximo à Estação Rodoviária de Santa Maria, onde solicitam doações de lonas e alimentos à comunidade. (BRUM, 2000, p.05)

No ano de 2001, a situação dos indígenas em Santa Maria mudou em alguns aspectos. Com a posse da gestão do prefeito Antônio Valdeci Oliveira de Oliveira (2001-2009) no governo municipal, passaram a ser adotadas algumas políticas públicas que buscaram garantir mais dignidade a estes sujeitos. As ações adotadas visavam alcançar tanto o bem-estar com a construção da "Casa do Índio, como a visibilidade e valorização das culturas indígenas por meio do desenvolvimento da "Semana dos Povos Indígenas".

Sobre a Casa do Índio é possível afirmar que esta possibilitou maior comodidade e segurança aos Kaingang que vinham para Santa Maria, garantindo teto para até 35 pessoas. Porém, o estabelecimento funcionava somente como uma casa de passagem, ou seja, existia um prazo estabelecido pelo regulamento, estipulando a permanência máxima de 15 a 20 dias em seu interior, devendo ser abandonada após transcorrido o período. A casa foi uma iniciativa conjunta das Igrejas Católica Romana, Evangélica Luterana, Episcopal Anglicana e Metodista e estava situada no atual Parque da Medianeira.

De acordo com depoimento concedido por um responsável pela Casa do Índio (2019), essas questões de amparo aos indígenas estavam ligadas à Secretaria de Assistência Social e Direitos Humanos. Num primeiro momento, no início do funcionamento da casa e antes desta, a vinda dos indígenas para o município ocorria somente próximo de datas comemorativas como Natal e Páscoa, passando a ocorrer de forma mais intensa em todas as épocas do ano devido à estrutura e ao espaço oferecidos (ENTREVISTADO CASA DO ÍNDIO, 2019).

No espaço ocupado pelos indígenas no Parque da Medianeira, localizado aos fundos do Santuário Basílica Nossa Senhora da Medianeira, na Rua General Osório, $\mathrm{n}^{0} 150$, os conflitos eram recorrentes, o que acabou gerando um certo desconforto por parte de moradores da área circundante e da própria Igreja, levando ao fechamento da Casa no ano de 2006 (ENTREVISTADO CASA DO ÍNDIO, 2019). Com a desativação da Casa do Índio, a luta por um espaço fixo de moradia se tornou mais intensa. Visando a permanência em Santa Maria, alguns Kaingang passaram a alugar casas em bairros distintos ou a ocupar outra área de 
forma mais efetiva, como é o caso da formação da Aldeia Três Soitas, próxima da rodoviária.

A habitação em tal espaço gerou disputas com um indivíduo nãoindígena, resultando em processo de reintegração de posse em 30 de novembro de 2011 , tendo como partes o não-indígena (autor), o Grupo de Apoio aos Povos Indígenas (GAPIN) e, como réus, o grupo indeterminado de índios da comunidade Caingangues.

Neste mesmo ano, ocorreu um debate a respeito da permanência dos indígenas no ambiente urbano de Santa Maria por meio da "I Assembleia Popular Indígena". O evento tinha como proponentes os indígenas Mbyá Guarani do Arenal, os Kaingang que residiam no acampamento próximo da Rodoviária, assim como, os Kaingang que comercializavam apenas no centro de Santa Maria, tendo participação também dos Conselhos de Articulação Indígena Kaingang (CAIK) e de Articulação do Povo Guarani (CAPG).

Além dos proponentes, participaram, por meio de apoio, o Ministério Público Federal (MPF), o GAPIN, o Departamento de História da UFSM, a SEDUFSM, o Conselho Missionário Indigenista (CIMI), o Conselho de Missão entre Índios (COMIN), além do Diretório Central de Estudantes (DCE), Diretório de Estudantes do Curso de História da UFSM (DAQUIPALM) e o Levante Popular da Juventude (LEVANTE) (ASSEMBLEIA, 2011, p.01).

Referente à sentença do processo, o Juiz responsável, observando os fatos sociais pertinentes ao processo, reconheceu que os Kaingang estavam "vivendo em situações precárias, sem condições dignas de moradia, alimentação, saúde, educação, saneamento básico, etc." (SANTA MARIA, 2011) e que a não consideração destes princípios básicos e fundamentais de vida humana violava o mínimo existencial, devendo eles serem garantidos pelo órgão competente, ou seja, a FUNAI. Os Kaingang, ainda referidos na sentença, não deveriam continuar

submetendo-se às precárias condições de vida narradas
pelo MPF [...] e de conhecimento de toda a população
desta cidade de Santa Maria, inclusive deste Magistrado,
que frequentemente passa em frente ao local e presencia
as lamentáveis condições em que vivem aquelas
pessoas. (SANTA MARIA, 2011)

No que tange aos méritos, o Juiz garantiu o direito de ocupação provisório dos Kaingang na Aldeia Três Soitas, reconhecendo a habitação destes na área antes mesmo da elaboração do contrato de locação apresentado pelo autor, fatos embasados em provas testemunhais apresentadas em depoimentos. Porém, é válido assinalar que a sentença não determinou a permanência definitiva no espaço em litígio. Ao GAPIN foi reconhecida a ilegitimidade na ação e ao autor o pagamento de honorários advocatícios no valor de $1.500,00$ reais a ambos os réus (SANTA MARIA, 2011).

Atualmente ainda existem disputas e negociações quanto à área a ser ocupada pelos Kaingang. Esses passaram por uma mudança, saindo 
do terreno até então habitado, próximo da rodoviária de Santa Maria, e passando a residir em Canudos, em região mais afastada do centro.

\section{Considerações Finais}

A inserção dos Kaingang na sociedade Fog (não indígena) não implica um abandono puro e simples da cultura e identidade ancestral, indo de encontro ao assimilacionismo proposto por um nacionalismo homogeneizante. Na verdade, ela corrobora diferentes práticas a partir das quais é possível perceber a utilização de instrumentos de maneira consciente, sejam estes a educação bilíngue, a organização de eventos públicos ou a própria disputa no que se refere ao reconhecimento da ocupação de territórios tradicionais.

Observa-se, diante do exposto, que em muitos casos ocorrem divergências entre interesses do Estado e dos povos indígenas, podendo citar, como exemplo, os termos utilizados para referenciar os territórios demarcados. Apesar das situações resultantes da expropriação de terras e do contato com colonizadores, os indígenas continuaram ali, presentes e jogando com as cartas que Ihes favoreciam, fazendo valer seus interesses e tendo suas próprias interpretações a respeito da História, como é o caso da diferenciação entre o tempo ancestral e o tempo atual. Estas modificações, principalmente como consequência da redução das terras tradicionais, promovem, na atualidade, especialmente a partir da Constituição de 1988, um efeito "sanfona", determinado pela redução seguida pela busca por territórios reconhecidos como tradicionais, marcando as mobilidades desempenhadas já pelos ancestrais Kaingang.

A etnogênese dos Kaingang, especificamente dos que habitam a Aldeia Três Soitas em Santa Maria, possui elementos que implicam a dinâmica de organização e reconhecimento identitário do tempo presente, estabelecida pelo contato com colonizadores imigrantes e pelas ações do Estado por meio da perspectiva assimilacionista baseada na transformação dos indígenas em trabalhadores nacionais e pela redução territorial empreendida pela política dos aldeamentos. É importante destacar, percebidas tais interferências, que existe uma relação muito próxima entre as etnogêneses e seu contexto histórico de desenvolvimento. A partir dos aldeamentos, ocorreram muitas modificações que implicaram ressignificações e práticas de indígenas da atualidade que exercem as mobilidades territoriais em busca de melhores condições de vida, como é o caso da venda de artesanato e da ocupação de espaços urbanos e públicos.

Por meio da análise do corpus documental selecionado, na tentativa de perceber os variados pontos de vista, nota-se, em comum, uma certa dificuldade na efetivação de políticas públicas permanentes para com as populações indígenas. Estes grupos articulados acabam por não encontrar condições sociais e ambientais adequadas para a sobrevivência física e cultural nas Terras Indígenas demarcadas pelo Estado e também não recebem a devida assistência nos centros urbanos, que passam a ocupar em número cada vez maior a partir dos anos 2000. A adoção de 
medidas paliativas que visam somente amenizar as situações de dificuldade, como é o caso da Casa do Índio, cria incentivos a outras famílias para buscarem os centros urbanos com o intuito de comercializar artesanato e adquirir assistência médica e social.

Inserido nos parâmetros analíticos da Nova História Indígena, percebe-se este processo enquanto resultante de um amálgama de fatores que arregimentam situações do passado (perdas humanas, redução de territórios) e do presente (aplicação de leis que visam garantir direitos fundamentais como a diferença, a educação bilíngue, e a terra). Incentivados por dificuldades, os Kaingang exercem suas mobilidades de acordo com interesses que lhes convêm, respeitando e utilizando a memória compartilhada e a oralidade enquanto ferramentas norteadoras das ações no presente.

As etnogêneses não são processos simples, pelo contrário, são compostas por diversas variantes, seja pelo sentimento de pertencimento e compartilhamento de um passado em comum, ou através de meios jurídicos que reconhecem tais ressurgimentos como legítimos em um período atual. O que se pode concluir é que o dinamismo se faz presente em todas as instâncias das culturas, não se restringindo apenas para aquelas não-indígenas. Ademais, o fato de ocorrerem transformações muitas vezes tidas como corruptoras de uma suposta identidade ancestral e estática, criando homogeneizações em prol do nacionalismo, não exclui a possibilidade de recriação de elementos associados a um passado específico dos Kaingang. 


\section{Fontes}

A RAZÃO, Santa Maria, 1999-2002.

BORELLI, Viviane. Lembranças e tristezas no Dia do Índio. A Razão, Santa Maria, 20/04/1999. no 164. Geral, p.07.

BRUM, Eliane. Índios pedem ajuda de SM. A Razão, Santa Maria, 06/04/2000, Geral, p.05.

TRANSCRIÇÃO DA ENTREVISTA COM OS ÍNDIOS KAINGANGS SANTA MARIA. In. WOLTMANN, D., Comunidade Indígena "Kaingang" na cidade de Santa Maria/RS: É possível fiscalizar e proteger o meio ambiente e a saúde sem prejudicar a cultura indígena?, 2012.

ENTREVISTADO A. depoimento [abr. 2019]. Entrevistador: E. Perius. Santa Maria: Aldeia Kaingang Três Soitas. Entrevista concedida ao Projeto Aldeia Três Soitas: memória, identidade e territorialidade Kaingang em Santa Maria.

ENTREVISTADO B. depoimento [jun. 2019]. Entrevistador: E. Perius. Santa Maria: Aldeia Kaingang Três Soitas. Entrevista concedida ao Projeto Aldeia Três Soitas: memória, identidade e territorialidade Kaingang em Santa Maria.

I ASSEMBLEIA POPULAR INDÍGENA DA CIDADE DE SANTA MARIA/RS, Santa Maria, 2011.

REMPEL, M. B.; KONRAD, D.A. A compreensão das Práticas Educativas Guarani e Kaingang para a implementação da Educação Escolar Indígena e o Cumprimento da Lei 11.645 no Município de Santa Maria, Relatório Prolicen/UFSM, Santa Maria, 2012.

SANTA MARIA. Justiça Federal. Seção Judiciária do Rio Grande do Sul. Reintegração/Manutenção de posse, No 5009281-91.2011.4.04.7102, 30/11/2011. 


\section{Referências Bibliográficas}

ALBERTI, Verena. Manual de História Oral. 3 ed. Rio de Janeiro: Editora FGV, 2005.

ALMEIDA, Maria Regina Celestino de. Identidades étnicas e culturais: novas perspectivas para a história indígena. In: ABREU, Martha; SOIHET, Rachel. (orgs.). Ensino de História: Conceitos, temáticas e metodologia. Rio de Janeiro: Casa da Palavra, 2003.

ALMEIDA. Maria Regina Celestino de. Os índios na história do Brasil. Rio de Janeiro: Editora FGV, 2010.

AMPARO, Sandoval dos Santos. Sobre a organização espacial dos Kaingang, uma sociedade indígena Jê Meridional. 2010. 117 f. Dissertação (Mestrado em Arquitetura e Urbanismo) - Universidade de Brasília, Brasília, 2010.

BARTOLOMÉ, Miguel Alberto. As etnogêneses: velhos atores e novos papéis no cenário cultural e político. Mana, Rio de Janeiro, n.12, p 39-68, 2006.

BECKER, Ítala Irene Basile. O índio Kaingang no Rio Grande do Sul. São Leopoldo: Ed. UNISINOS, 1976.

BESSA FREIRE, José Ribamar. Cinco ideias equivocadas sobre os índios. Revista Ensaios e Pesquisa em Educação, Rio de Janeiro, v.1, 2016.

BOCCARA, Guillaume. Mundos nuevos en las fronteras del Nuevo Mundo. Débats, 2005. Disponível em: http://journals.openedition.org/nuevomundo/426. Acesso em 30/04/2019.

BOCCARA, Guillaume. Génesis y estructura de los complejos fronterizos euroindígenas: repensando los márgenes americanos a partir (y más allá) de la obra de Nathan Wachtel. Memoria Americana, p. 21-52, 2005.

BONFIL-BATALLA, Guillermo. México profundo: una civilización negada. Editorial Grijalbo S.A., México D.F., 1990.

BRAGA, Danilo. A História dos Kaingang na luta pela terra no Rio Grande do Sul: do silêncio, à reação, a reconquista e a volta para casa (1940-2002). Dissertação (Mestrado em História), UFRGS, 2015.

BRASIL. Constituição Federal de 1988. Promulgada em 5 de outubro de 1988. Disponível em <http://www.planalto.gov.br/ccivil_03/constituicao/constituição.htm> Acesso em 07/11/2019.

BRINGMANN, Sandor Fernando. Entre os índios do sul: uma análise da atuação indigenista do SPI e de suas propostas de desenvolvimento educacional e agropecuário nos Postos Indígenas Nonoai/RS e Xapecó/SC (1941-1967). Tese de Doutorado, Florianópolis, 2015. 
CATROGA, Fernando. Memória, História e historiografia. Rio de Janeiro: FGV, 2015.

CAVALCANTE, Thiago Leandro Vieira. Etno-história e história indígena: questões sobre conceitos, métodos e relevância da pesquisa. História, São Paulo, v.30, n.1, p. 349$371,2011$.

CAVALCANTE, Thiago Leandro Vieira. Terra indígena: aspectos históricos da construção e aplicação de um conceito jurídico. História, São Paulo, v.35, 2016.

CRUIKSHANK, Julie. Tradição oral e história oral: revendo algumas questões. Cap. 11 In. AMADO, Janaína; FERREIRA, Marieta de Moraes (orgs.) Usos \& abusos da história oral. 8ed. Rio de Janeiro: FGV, 2006.

FERREIRA, Marieta de Moraes. História, tempo presente e história oral. Topoi, Rio de Janeiro, v.3, n.5, p. 314-332, 2002.

FLORES, Andressa de Rodrigues. A Educação Escolar de Índios Kaingang em Santa Maria/RS. Anais do III Encontro de Pesquisas Históricas - PPGH/PUCRS. Porto Alegre, p.102-115, 2016.

FLORES, Andressa de Rodrigues. Relatório Figueiredo: o teor dos crimes cometidos pelo SPI contra os povos originários nos postos indígenas do Rio Grande do Sul (1963-1967). Anais do XXIX Simpósio Nacional de História - Contra os preconceitos: História e democracia, 2017.

FRANCISCO, Aline Ramos. Relações políticas entre nativos Kaingang, fazendeiros e poder público provincial e imperial (1808-1861). Anais do XXVI Simpósio Nacional de História - ANPUH, São Paulo, 2011.

FREITAS, Edinaldo Bezerra de. B. Fala de índio, História do Brasil: o desafio da EtnoHistória Indígena. História Oral, v.7, p.181-197, 2004.

GARLET, Marinez. Entre cestos e colares, faróis e parabrisas: crianças Kaingang em meio urbano. Porto Alegre, Dissertação (mestrado em Serviço Social) - PUCRS, 2010.

GONZÁLEZ CASANOVA, Pablo. Colonialismo interno (uma redefinição). In. BORON, Atilio; AMADEO, Javier; GONZALEZ, Sabrina. A teoria marxista hoje. Problemas e perspectivas, Buenos Aires: 2007.

GONZÁLEZ, Everaldo Tadeu Quilici.; LIMA, Gisele Laus da Silva Pereira. Guerra Justa: a pretensão civilizatória e os direitos humanos na ocupação da América Latina. 1ed. CONPEDI, Uberlândia, p. 11919-11934, 2012.

GOULART, Jorge Salis. A formação do Rio Grande do Sul. $4^{\text {a }}$ ed. Porto Alegre, Martins Livreiro, Caxias do Sul, EDUCS, 1985.

GROULX, Lionel-Henri. Contribuição da pesquisa qualitativa à pesquisa social. In. A pesquisa qualitativa: enfoques epistemológicos e metodológicos. Vários autores Tradução de Ana Cristina Nasser. Vozes, Petrópolis, p. 95-124, 2008. 
HECK, Egon Dionisio. Os índios e a caserna: políticas indigenistas dos governos militares - 1964 a 1985. Campinas, São Paulo, 1996.

IGGERS, George. Desafios do século XXI à historiografia. História da historiografia. Ouro Preto: n.4, p. 105-124, 2010.

JACQUES, João Cezimbra. Assuntos do Rio Grande do Sul, $3^{\text {a }}$ ed., Martins Livreiro, Porto Alegre, 1997.

KUJAWA, Henrique; TEDESCO, João Carlos. Demarcações de terras indígenas no Norte do Rio Grande do Sul e os atuais conflitos territoriais: uma trajetória histórica de tensões sociais. Tempos Históricos, Marechal Cândido Rondon: v.18, n.2, p. 67-88, 2014.

LAPPE, Emeli. Espacialidades sociais e territoriais Kaingang: terras indígenas Foxá e Por Fi Gâ em contextos urbanos dos rios Taquari-Antas e Sinos. 2007. Dissertação (Mestrado em Ambiente e Desenvolvimento) - Univates, Lajeado, 2015.

LAPPE, Emeli; LAROQUE, Luís Fernando da Silva. Indígenas e Natureza: a reciprocidade entre os Kaingang e a natureza nas Terras Indígenas Por Fi Gâ, Jamã Tÿ Tãnh e Foxá. Desenvolvimento e Meio Ambiente, v. 34, p. 147-156, 2015.

LAROQUE, Luís Fernando da Silva. Fronteiras geográficas, étnicas e culturais envolvendo os Kaingang e suas lideranças no Sul do Brasil (1889-1930). Pesquisas, Antropologia. São Leopoldo: Ed. UNISINOS, 2007.

LINARES, Federico Navarrete. Hacia otra historia de América. Nuevas miradas sobre el cambio cultural y las relaciones interétnicas. Universidad Nacional Autónoma de México, Instituto de Investigaciones Históricas, Históricas Digital, p.87-157, 2015.

MARTINS, Estevão Chaves de Rezende. Teoria e filosofia da História. Contribuições para o ensino de História. Curitiba: W. A. Editores, 2017.

MATOS, Júlia Silveira; SENNA, Adriana Kivanski de. História oral como fonte: problemas e métodos. Historiæ, Rio Grande, v.2 n.1, p. 95-108, 2011.

MONTEIRO, John Manuel. Negros da terra: índios e bandeirantes na origem de São Paulo. São Paulo: Companhia das Letras, 1994.

MOTA, Lúcio Tadeu. Os índios Kaingang nos campos do Brasil meridional na metade do século passado. In: MOTA, Lúcio Tadeu; NOELLI, Francisco S.; TOMMASINO, Kimiye (Org.). Uri e Wãxi: estudos interdisciplinares dos Kaingang. Londrina: EDUEL, 2000.

NASCIMENTO, José Antônio Moraes do. "Muita terra para pouco índio": ocupação e apropriação dos territórios Kaingang da Serrinha/RS. São Leopoldo: Editora Oikos, 2014.

NONNENMACHER, Marisa Schneider. Aldeamentos Kaingang no Rio Grande do Sul: século XIX. Porto Alegre: EDIPUCRS, 2000. 
OLIVEIRA, Lizete Dias. Síntese Histórica do Povoamento do Rio Grande do Sul. SILVEIRA, Elaine da; OLIVEIRA, Lizete Dias de. Etnoconhecimento e saúde dos povos indígenas do Rio Grande do Sul. Canoas: Editora da ULBRA, p. 21-22, 2005.

ORGANIZAÇÃO INTERNACIONAL DO TRABALHO. Convenção $n^{\circ} 169$ sobre povos indígenas e tribais e Resolução referente à ação da OIT / Organização Internacional do Trabalho. Brasilia: OIT, 2011.

ORLANDI, Eni Pucinelli. Terra à vista: Discurso do Confronto: Velho e Novo Mundo. Campinas: Editora Unicamp, 2008.

PACHECO DE OLIVEIRA, João. Uma etnologia dos “índios misturados"? Situação colonial, territorialização e fluxos culturais. Mana, vol. 4, Rio de Janeiro: p.47-77, 1998.

PERIUS, Eduardo. Aldeia Kaingang Três Soitas: trajetória, lutas pela terra e protagonismo indígena em Santa Maria. 2017. Monografia (Graduação em História) UFSM, Santa Maria, 2017.

POLLAK. Michael. Memória, Esquecimento, Silêncio. Estudos Históricos, Rio de Janeiro, vol. 2, n. 3, p. 03-15, 1989.

RIBEIRO, Zico. Caracterização sociodinâmica da comercialização do artesanato Kaingang na Terra Indígena de Guarita. Monografia (Pós-Graduação em Desenvolvimento Rural Sustentável e Agricultura Familiar) - UFFS, Cerro Largo, 2013.

ROSADO, Rosa Maris; FAGUNDES, Luis Fernando Caldas (orgs.). Presença indígena na cidade: reflexões, ações e políticas. Núcleo de Políticas para Povos Indígenas. - Porto Alegre: Gráfica Hartmann, 2013.

SCHMITZ, Pedro Ignácio; NAUE, Guilherme; BECKER, Ítala Irene Basile. Os aterros dos campos do Sul: a Tradição Vieira. SCHMITZ, P. I. (ed.). Arqueologia do Rio Grande do Sul, Brasil - Documento 5. São Leopoldo: Instituto Anchietano de Pesquisas/UNISINOS, p. 101-124, 2005.

SCHWINGEL, Kassiane; LAROQUE, Luís Fernando da Silva; PILGER, Maria Ione. (orgs.). Jamã Tý Tãnh. Ig Vẽj Kaingang. Morada do Coqueiro. Jeito de viver Kaingang. São Leopoldo: Oikos, 2014.

SILVA, Giovani José da. Diálogos entre História e Antropologia em contextos coloniais e pós-coloniais. In. SOUZA, Fábio Feltrin de., WITTMANN, Luisa Tombini. (Orgs.). Protagonismo indígena na história. Tubarão: Copiart; UFFS, p. 207-230, 2016.

SILVA, Juciane Beatriz Sehn da; LAROQUE, Luís Fernando da Silva. A história dos Kaingang da Terra Indígena Linha Glória, Estrela, Rio Grande do Sul/Brasil: Sentidos de sua (re)territorialidade. Sociedade \& Natureza, Uberlândia, v.24, n. 3, p. 435-448, 2012.

SILVA, Sérgio Baptista. Etnoarqueologia dos grafismos "Kaingang": um modelo para a compreensão das sociedades Proto-Jê meridionais. 2001. Tese (Doutorado em Antropologia Social) - USP, São Paulo, 2001. 
TAYLOR, Dyana. Atos de transferência In: $O$ arquivo e o repertório: performance e memória cultural nas Américas. Belo Horizonte: UFMG, p. 25-90, 2013.

TOMMASINO, Kimiye. A história dos Kaingang da Bacia do Tibagi: uma Sociedade Jê Meridional em Movimento. 1995. Tese (Doutorado em Antropologia) - USP, São Paulo, 1995.

TOMMASINO, Kimiye. Os novos acampamentos (wãre) Kaingang na cidade de Londrina: mudança e persistência numa sociedade Jê. Londrina: Mediações v. 3, n. 2, p. 66-71, 1998.

TOMMASINO, Kimiye.; ALMEIDA, Ledson Kurtz de. Territórios e territorialidades Kaingang: a reinvenção dos espaços e das formas de sobrevivência após a conquista. Mediações, Londrina, v. 19 n. 2. p. 18-42, 2014.

VEIGA, Juracilda. Aspectos Fundamentais da Cultura Kaingang. Campinas, São Paulo: Editora Curt Nimuendajú, 2006.

VEIGA, Juracilda. Organização Social e Cosmovisão Kaingang: uma introdução ao parentesco, casamento e nominação em uma sociedade Jê Meridional. 1994. 226 f. Dissertação (Mestrado em Antropologia Social) - IFCH - UNICAMP, Campinas, 1994.

WAGNER, Carlos; ANDREATTA, Humberto; PEREIRA, André. A Guerra dos Bugres: A Saga da Nação Caingangue no Rio Grande do Sul. tchê! Editora Ltda., Porto Alegre, 1986.

WISNIEWSKI, Fernanda. A Terra Indígena do Guarita -RS e o seu processo de formação. Anais do XXVI Simpósio Nacional de História - ANPUH. São Paulo, 2011. 